\title{
STAKEHOLDER ENGAGEMENT AND VALUE CO-CREATION VIA SOCIAL MEDIA: A CASE STUDY OF CONTAINER SHIPPING COMPANIES
}

\section{Gül DENKTAŞ ŞAKAR ${ }^{1}$ Ebru SÜRÜCÜ BALCI ${ }^{2}$}

\begin{abstract}
The importance of value co-creation through value propositions of the companies has been studied considerably from the lens of Service Dominant Logic (SDL). Although the main focus has solely been on customers, increasing role of stakeholders in value co-creation should also be considered. Social media has been suggested as an effective tool for establishing close relationships with stakeholders. Although businesses give priority to their communication with their customers in social media, it is also known that their stakeholders other than customers are influenced by the social media messages. The present study aims to figure out the social media interactions of two selected container shipping companies through their relationships with stakeholders and to identify how such interactions constitute the valuein-use. For this purpose, a case study approach was employed and both interviews and desk research was conducted. Findings revealed that customization with regards to stakeholder and social media channel and content creation was critical in value propositions. Stakeholders as operant resources contributed greatly to the creation of value-in-use. Knowledge sharing, continuous communication, sensing, and adaptation were suggested as the main enabler for value-in-use. The study contributed to the theoretical discussion over stakeholders' role in the value co-creation processes of the companies via social media.

Keywords: Social Media, Stakeholder Engagement, Value CoCreation, Service-Dominant Logic, Container Shipping Companies.
\end{abstract}

\footnotetext{
${ }^{1}$ Dokuz Eylül Üniversitesi, Denizcilik Fakültesi, Lojistik Yönetimi Bölümü, Doç. Dr., mail: gul.denktas@deu.edu.tr

${ }^{2}$ Manisa Celal Bayar Üniversitesi, İșletme Fakültesi, Uluslararası Lojistik Bölümü, Araş. Gör., mail: ebru.surucu@cbu.edu.tr

3 Bu çalışmanın bir kısmı 28-30 Eylül 2017 tarihlerinde Trabzon'da düzenlenen 22.Pazarlama Kongresi'nde sunulmuştur ve bildiriler kitabında yer almıştır. Bu çalışma, bildiri halinin geliştirilmiş ve değiştirilmiş halidir.
} 


\section{SOSYAL MEDYA ARACILIĞIYLA PAYDAŞ KATILIMI VE BİRLİKTE DEĞER YARATIMI: KONTEYNER TAŞIMACILIĞI YAPAN İŞLETMELER ÜZERİNE BİR VAKA ÇALIŞMASI ÖZ}

Değer önerileri aracılığıla birlikte değer yaratımının önemi hizmet baskın mantık bakış açısıyla oldukça yoğun bir şekilde incelenmiştir. Her ne kadar ana odak noktası müşteriler olsa da, birlikte değer yaratımında paydaşların artan rolünün de göz önüne alınması gerekmektedir. Sosyal medya, paydaşlarla yakın ilişkiler kurmak adına etkili bir araç olarak önerilmektedir. İşletmeler sosyal medya aracılığıla müşterileriyle iletişime öncelik verseler de, müşteriler dışındaki paydaşların da sosyal medya mesajları ile etkilendikleri bilinmektedir. Bu çalışma, seçilen iki konteyner taşımacılığı yapan işletmenin sosyal medya etkileşimlerini paydaşlarla olan ilişkileri üzerinden anlamaya ve bu etkileşimlerin kullanımdaki değeri nasıl oluşturduğunu belirlemeyi amaçlamaktadır. Bu amaçla bir vaka çalışması yaklaşımı uygulanmıştır ve hem görüşme hem de masa başı araştırması yapılmıştır. Bulgular, paydaşlar ve sosyal medya kanalına yönelik kişiselleştirme ile içerik yaratımının işletmelerin değer önerilerinde önemli olduğunu ortaya koymuştur. İslem doğuran kaynaklar olarak paydaşların kullanımda değer yaratmaya oldukça katkı sağladığı görülmüştür. Bilgi paylaşımı, sürekli iletişim, algılama ve adaptasyon kullanımda değerin ana sağlayıcıları olarak önerilmiştir. Çalışma, paydaşların sosyal medya aracılığıyla şirketlerin ortak değer oluşturma süreçlerindeki rolüne ilişkin teorik tartışmaya katkıda bulunmuştur.

Anahtar Kelimeler: Sosyal Medya, Paydaş Katılımı, Birlikte Değer Yaratımı, Hizmet Baskın Mantık, Konteyner Taşımacılı̆̆ı Yapan Issletmeler

\section{Introduction}

Social media is gaining ground in various industries and companies can communicate with various parties through the opportunities provided by different social media channels. Social media has been considered as a platform for knowledge exchange, idea generation, and relationship building. Possible consequences of social media use on consumer markets were studied considerably. As Agerdal-Hjermind (2014) highlighted, B2C cases investigating the corporate social media coverage are mainly higher compared to $\mathrm{B} 2 \mathrm{~B}$ cases on social media usage. However, there has been an increasing interest in the social media use in B2B organizations and studies 
mainly focused on learning with and from customers via social media (Jussila et al. 2012); B2B companies' usage, measurement practices, and barriers in the era of social media (Järvinen et al. 2012); determinants of social media adoption (Siamagka et al. 2015); B2B customers' behavior regarding their social media use (Keinänen and Kuivalainen, 2015); the impacts of salesperson information communication behaviors considering the use of social media and customer satisfaction (Michaelidou et al. 2011; Agnihotri et al. 2016); B2B companies' perceptions of and attitudes toward social media (Veldeman et al. 2015); content creation in social media by B2B companies (Huotari et al. 2015). To sum up, the literature to date has largely concentrated on both B2B companies' attitudes towards social media and their customers' role in their social media. However, there are various stakeholders of companies apart from their customers and the organizations need to establish close connections with such actors through social media. In addition, the studies related to social media considering the stakeholder perspective are still extremely limited and a solid grounding for understanding how social media is used for stakeholder engagement is missing (Krumay and Geyer, 2016, p.254). Vargo (2009) asserted that value creation through reciprocal service provision in a networked and co-creative way is critical. Hence, social media can be suggested as a valuable tool for connecting the companies with their stakeholders and value can be co-created as a result of such exchange. Consequently, value co-creation concept with its related components in case of social media and stakeholder engagement remains unclear. Against this backdrop, this study aims to; (1) reveal how value propositions of the shipping companies and the stakeholders co-create value through social media use and (2) develop an understanding of the selected shipping companies' understanding of social media's use and its impacts in stakeholder engagement and value co-creation (value-inuse). To achieve the objectives of the study, the following three research questions are proposed:

- What are the components of value propositions in achieving stakeholder engagement via social media?

- What role do the stakeholders have in value co-reaction through social media?

- What are the key enablers of value-in-use in stakeholder engagement via social media? 
This paper proceeds as follows: in the next section, the relevance between the stakeholder marketing concept and value co-creation is discussed and the related literature is reviewed. Then, a literature review on the role of social media in stakeholder engagement is provided. This is followed by a discussion of the methodology of the study and presentation of the findings of the case study. Finally, conclusions are discussed, limitations of the study are presented and avenues of future research are suggested.

\section{Value Co-Creation through Stakeholder Marketing}

Many actors interact with the companies and the companies in case of complex decision-making situations should consider those stakeholders. In rapidly changing, competitive and turbulent marketing environment, performance sustainability of the companies has broadened to cover additional issues that reach far beyond the return to shareholders (Clulow, 2005, p. 978). Freeman's (1984) seminal work highlighted the importance of the stakeholders' role in organizations. As Freeman (1984, p. 46) defined a stakeholder is "any group or individual who can affect or is affected by the achievement of the organization's objectives". Stakeholders can be categorized as the primary (communities, customers, employees, suppliers, and financiers) as the ones that define the business and secondary players (government, competitors, consumer advocate groups, social interest groups, and media) impacting the relationships with the primary ones (Freeman et al. 2007, Gould, 2012, p.5). Although stakeholder theory was gaining ground mainly in business ethics and management literature (Parmar et al. 2010), integration of multiple stakeholders to the marketing processes of the companies has been evolving over the last decade (Sen et al. 2006). Contribution from management literature has enabled the development of stakeholder theory for marketing by suggesting a framework for understanding how various stakeholders are affected by marketing efforts (Hull et al. 2011). Hillebrand et al. (2015, p. 411) argued that marketing academia should change its perspective by focusing on the relationships of the company with the stakeholders rather than focusing on only customers. Several scholars (Miller and Lewis, 1991; Duncan and Moriatry, 1998; Payne et al. 2005; Jurgens et al., 2010) concentrated on the integration of stakeholders with marketing practices in their studies.

Following the integration of marketing topics with stakeholder theory, emerging areas of research in marketing domain 
has also increased. Service-Dominant Logic (SDL) providing a solid ground for the identification of the value concept within the perspective of both the company and the customer, suggests that an organization should focus on considering the customer as a resource contributing to the creation of value (Vargo and Lusch, 2008). This actually makes the customer a co-creator of value. It is about collaborating with and learning from customers rather than simply being customer-oriented. An SDL perspective focuses on the understanding that value is defined by and co-created with the consumer. On the other hand, companies are viewed as co-producers or co-creators of value that participate in the value creation processes of the customer through making value propositions and providing resources for customers (Payne and Frow, 2005, Vargo and Lusch, 2004, Payne et al. 2008). Interactions between the company and the customers play a critical role in supporting the value-creating processes since such interactions permit companies to support customer's value actualization processes. The companies evolve as critical participants in the customer's value-creating process rather than acting as passive contributors (Grönroos and Ravald, 2011; Grönroos, 2008). Two main types of resources are highlighted in SDL as operant and operand resources (Vargo and Lusch, 2004). Operand resources can be considered all tangibles resources (facilities and infrastructure-related components) on which an operation is conducted to produce an effect. Operant resources (knowledge, skill, capabilities and all related intangible resources) are considered to act on operand resources (Constantin and Lusch, 1994). Integration of such resources results in "value-inuse" (Vargo and Lusch, 2008, p.149). Grönroos (2011) pointed out that the customer is the value creator when adopting a value-in-use notion. Apart from value-in-use, SDL focuses heavily on "value propositions" constituting relationships among service systems (Vargo et al. 2008, p.148).

In the light of the recent studies on stakeholder relations and marketing practices, there is an increasing attention on the perspective of value-creation, value exchange and value propositions through the lenses of stakeholder relations and stakeholder engagement. This coincides well with (SDL) perspective since SDL is suggested as an understanding promoting collaborative, interactive and greater value co-creating activities between stakeholders (Abela and Murphy, 2008). Vargo and Lusch (2008) firstly focused on customer-supplier relationships and then they developed it by 
including value configurations of many parties interacting with each other across networks. This supports the contribution of involvement of many parties to the value creation process. Normann and Ramirez (1993) made the first contribution regarding the importance of non-customer stakeholders and their potential for the co-creation of new forms of value. By focusing on the creation of value, Gummesson (2008) argues that relationships with other stakeholders may influence the customer relationships so that a diverse network of stakeholders creates value. Rather than building dyadic relationships, stakeholder marketing concentrates on cocreation in network relationships (Frow and Payne, 2011). Clarkson (1995) declared that organizations should focus on understanding the various stakeholder interests rather than limiting their focus on increasing the benefits of one stakeholder. The exchange of the value is critical for the companies since how a firm treats its customers influences the attitudes and behavior of the firm's employees, and how a firm behaves towards the communities in which it operates influences the attitudes and behavior of its suppliers and customers (Cording et al. 2014). In case of value creation process, SDL argues that companies can only suggest value propositions and value is created during the in-use experience. As Frow and Payne (2011) discussed, the companies should understand and manage the in-use experience with their stakeholders. Since value co-creation processes of the company may differ from one stakeholder to another, cocreation of value propositions with each stakeholder must be managed carefully. The relationship between the value proposition concept and stakeholder perspective has received little attention from the perspective of SDL (Frow and Payne, 2011). By supporting this, Smith et al. (2010) pointed out that the importance of value creation and asserted that value creation was neglected in the stakeholder literature. Frow and Payne (2011) pointed out a critical gap in the literature by stating that value propositions can be used to identify opportunities for value co-creation and creation of stability within stakeholder relationships.

\section{Role of Social Media in Stakeholder Engagement}

Social media is changing the business landscape and the way that the businesses communicate with their customers and stakeholders. Social media is seen as a new medium of business communication considering the latest development on the Internet. Social media is also gaining ground in the business-to-business 
community (Rapp et al. 2013) since developing good relationships with target market is the key success in B2B marketing (Blaney, 2013). As Gillin and Schwartzman (2011) claimed B2B companies should try to gain more from social media compared to B2C companies since it becomes possible to affect B2B relationships at almost every level. Hence social media can be a valuable tool for businesses to deliver their expertise and experience more easily by developing close relationships. Social media can positively affect the company's performance and customer engagement levels due to the value created by customer interactions (Trainor, 2012).

Interactions of the companies can not only be limited to their customers via social media and stakeholders can also be considered as the critical target groups for such interactions. Relationships with stakeholders require structured, interactive and bi-directional interaction (Unerman, 2007) and social media can be considered as a valuable tool for developing the relationships between the organizations and their stakeholders. In addition, social media may allow stakeholders to communicate with the company where they have some control over communication and feel truly involved (Vernuccio, 2014). Many opportunities of social media for stakeholder groups can be listed as; providing information, demonstration of common topics, sharing opinions and these all affect the stakeholder engagement efforts (Lutz and Hoffman, 2013).

Stakeholder engagement is defined by Pedersen (2006) as a process including some filters such as choosing the right partners and defining adequate responsibilities. This process can be more complex as the use of social media facilitates the coordination of more diverse groups (Hoffmann and Lutz, 2014). Engagement can be considered as an important topic for the development of on-going relationships with related stakeholders (Smith et al. 2011), component in value creation (Baden, 2010) and a facilitator for the development of collaboration and achievement of shared goals (Andriof and Waddock, 2002). Engagement constitutes "alchemy" of relationships, where resources are transformed (Nelson and Zadek, 2000). Krick et al. (2005) identified the shift in stakeholder engagement from responding to the pressure of interest groups in incorporating stakeholder engagement to their governance structures in order to maintain strategic competitiveness. Hence stakeholders are accepted critical for a process of external engagement (Jawahar and McLaughlin 2001; Waddock 2005). Vargo (2009) and Vargo et al. (2006) highlighted that the purpose of 
interactions between stakeholders is to co-create some form of value and stakeholders should be included in the value co-creation processes as well. In this case, social media can act as an integrator tool for the stakeholders and the organizations in order to co-create value. Building upon this, the current study investigates the role of social media in stakeholder engagement and value co-creation between the companies and their stakeholders. The literature review identifies the main components of stakeholder engagement and value co-creation via social media. These components are summarised in Figure 1 and they were used to design the interview protocol as explained in the following section and the analysis of the findings of the interviews and the desk research.

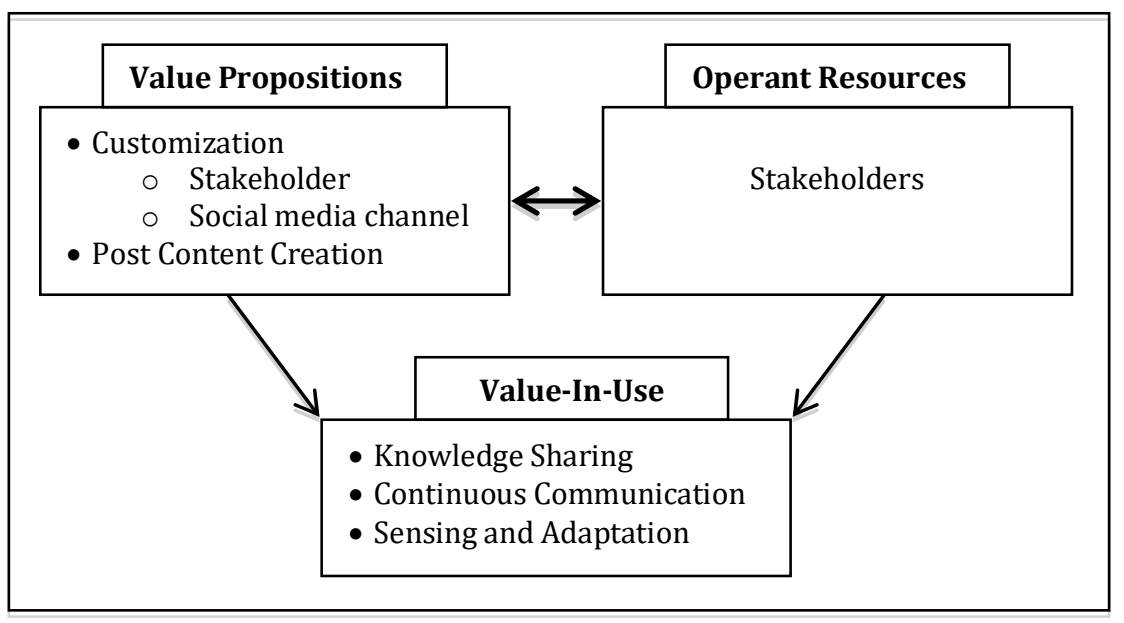

Figure 1: Emergent Theoretical Themes

\section{Methodology}

A case study is a research approach which aims to reveal the current dynamics in a single setting (Eisenhardt, 1989). Yin (2003) argued that case study approach is more suitable for answering "how" and "why" questions and where the researcher has little control or no control over events or subjects. This supported the use of the case study method in the current study since "how" and "why" questions were frequently used in order to understand how the selected container shipping companies use social media and engage with their stakeholders and co-create value as a result of such engagement. Based on the exploratory characteristics of this study, a multiple parallel case study was considered as the appropriate 
design. A multiple case design was adopted in this research since it provides an opportunity for deeper understanding and comparison. It is important to note that multiple cases are not chosen to support generalization, but rather studying such multiple cases can result in better understanding and theorizing about still larger collections of cases (Stake, 2005). In this study, two purposively selected container shipping companies were considered sufficient to generate theoretical insights. Also, Creswell (2007) argued the more case studies, the more the overall analysis is diluted.

The case study typically uses a combination of specific methods: interview, observation, and documentary sources, etc. Using multiple sources of evidence within a case study approach plays an important role for the researcher to focus on wider historical, attitudinal and behavioral issues (Yin, 2003). Since a qualitative case study approach provides room for the investigation of complex and dynamic processes (Cassell and Symon, 1994), and investigates the emerging views (Adams and Schvaneveldt, 1985), it was considered as the appropriate method for getting a deeper insight regarding the cases observed. In addition, the interaction between social media and stakeholder relationships is an underdeveloped area and has many gaps in the literature so that multiple case study design is employed in this study. Also, multiple case designs give an opportunity for richer and deeper analytical comparison (McCarthy et al. 2014, p.188).

Data on the case study firms were gathered through a combination of desk research including documents, reports, websites and face-to-face and e-mail interviews with two social media and pulse managers in case study companies. To familiarize researchers with shipping companies, desk research was important and it focused on social media presence of the case study companies, all types of digital media platforms, industry websites and key social media industry reports. With the help of desk research, researchers were able to identify the need for the research and had a more informed view from which to classify the findings and consecutive discussions. Face-to-face semi-structured interviews were conducted with social media executive of Arkas. Semi-structured interviews were employed in order to reach some important points and information about the role of social media in stakeholder engagement and value co-creation not only with customers but also with various stakeholders. The reasons for using this type of interview are that they provide flexibility in that the content and 
number of the questions may be changed from one party to another if required. The qualitative research design was adopted based on semi-structured interviews and e-mail interview, which provide indepth insights in a flexible and exploratory way (Bryman and Bell, 2011). The interview with Arkas's social media executive lasted one hour on 28.07.2017 and then, a follow-up e-mail interview was conducted with the social media manager as well. Since Maersk headquarters is located in Denmark, two e-mail interviews were conducted with the social media executive of Maersk on 28.07.2017 and 10.08.2017. An interview schedule was designed and piloted. The questions in the interviews were based on an extensive literature review (Vargo and Lusch, 2004; Vargo and Lusch, 2008; Frow and Payne, 2011; Bonsón and Ratkai, 2013; Järvinen et al. 2012; Jussila et al. 2012) on the role of social media in stakeholder engagement and value co-creation. Interview questions mainly included the role of social media in value co-creation and stakeholder engagement, main factors considered in post content creation, critical success factors in stakeholder engagement via social media, main strategies for value co-creation with stakeholders via social media. Face-to-face interviews were recorded and transcribed and there were supported by the field notes based on the observations of the authors in Arkas shipping company. The transcripts were approved by the interviewees. Participant checking was conducted since it brings rigor to the process (Creswell and Miller, 2000) as well as credibility in qualitative research (Lincoln and Guba, 1985).

Table 1 provides information regarding the selected cases in the study.

Maersk has become active in digital platforms since October 2011. In less than 11 months, Maersk attracted more than 400,000 fans on Facebook and constituted a presence in nine platforms with nine different purposes (Cambie, 2012). In 2012, Maersk won various awards for their social media campaigns; becoming an example for B2B companies. (Agerdal-Hjermind, 2014, p.7). Moreover, scholars from MIT and Harvard universities published case stories regarding the success of Maersk in social media (Wichmann, 2013, p. 3). In terms of the second case, Arkas has been one of the biggest contributors to Turkey's foreign trade by being the leader of private port management. While providing services with Marport, the highest volume container-handling port in Turkey (annual 2,3 million TEU capacity) and Autoport (Turkey's first car terminal with annual 400.000 vehicle capacity), Arkas acquired the 
partnership of Terminal del Golfo port to make use of its know-how in port sector abroad as well.

Table 1. Case Descriptions

\begin{tabular}{|l|c|c|}
\hline $\begin{array}{l}\text { Establishment } \\
\text { Date \& Place }\end{array}$ & Maersk & Arkas \\
\hline Fleet Capacity & $\begin{array}{c}639 \text { (244 owned - } \\
395 \text { chartered) }\end{array}$ & $\begin{array}{c}44 \text { (37 owned }-7 \\
\text { chartered) }\end{array}$ \\
\hline $\begin{array}{l}\text { Container Ship } \\
\text { Numbers }\end{array}$ & 590 container ships & 47 container ships \\
\hline TEU & $3,422,858$ & 73,731 \\
\hline $\begin{array}{l}\text { Container Fleet } \\
\text { Ownership Rank }\end{array}$ & 1 & 20 \\
\hline Revenue & $\$ 35,464$ (million) & n/a \\
\hline Employee Number & $\begin{array}{c}29,200 \text { employees } \\
(7,600 \text { seafarers) }\end{array}$ & $\begin{array}{c}7300 \text { employees } \\
62 \text { offices (14 in } \\
\text { Turkey, 24 in other } \\
\text { countries) }\end{array}$ \\
\hline $\begin{array}{l}\text { Currently Office } \\
\text { Numbers }\end{array}$ & $\begin{array}{c}324 \text { offices (in } 115 \\
\text { countries })\end{array}$ &
\end{tabular}

For this study, Maersk is chosen since it is in the first rank in the container fleet ownership and Maersk also won awards regarding its success in social media. Arkas is chosen as a case study firm since it was established in Turkey and it has the largest container fleet in Turkey ranking 24th in the world in a study on Container Fleet Ownership done by Clarkson Research Services Limited, while according to a report based on Alphaliner's analyses published in December by Dynamar B.V., Arkas Line ranks 20 th among international container shipping lines as of based on the number of vessels it operates and its total transportation capacity (Arkas, 2017). Besides, it was observed that the shipping and logistics industry in Turkey still lack an understanding of the importance of social media so that Arkas was considered since it invests in their social media platforms heavily and outsources it when necessary. 


\section{Findings and Discussion}

This section presents the findings of the study generated from the interviews and the desk research. Firstly, components related to the value propositions of the companies regarding stakeholder engagement via social media are identified. Then, stakeholders as resources are outlined. Value-in-use is explained from the perspective of stakeholder engagement via social media and enablers as continuous communication and knowledge sharing are discussed (see Figure 1).

\section{Value Propositions}

Social media is viewed as an integrator and a tool for the value co-creation process between the companies and the stakeholders. Value propositions consisted of the main content of the social media channels that the companies provided to their stakeholders and customization efforts of the company to make sure that each channel reaches the target stakeholders. The target audience is generally the stakeholder group of the company and there may be more than one target audience in accordance with the content of the post as well. On the other hand, stakeholders contribute to the value co-creation process through their comments to the posts and the popularity, virality and the commitment values of the posts may provide an insight regarding the social media effectiveness of the companies. All stakeholders may potentially be viewed as co-participants in the service provision (Laczniak, 2006) through their comments (including the commitment, popularity and virality metrics) and value cannot be created in isolation from stakeholders and the primary focus has been the value-in-use constituted as a result of such exchange. As Lusch and Webster Jr. (2011) pointed out, offering value of a particular kind is achieved with a value proposition and it is a marketing responsibility to ensure that such value propositions are communicated to "resourceproviding stakeholders". Value propositions are discussed under two main categories of content and customization (stakeholder and social media channel customization).

\section{Post Content Creation}

The content of the social media channels provides key aspects of the ways to communicate and engage with the stakeholders. Hence the first component in value propositions was considered as content where the main dialogue and interaction actually take place. Post 
content creation was highly mentioned during the interviews. Both shipping firms synchronize their social media contents and their marketing activities. Moreover, both firms reached consensus on determining the post content; (1) what firm wants to tell with the story in the post and (2) which stakeholders the firm aims to reach with the related content. For Maersk, the critical question for the creation of port content was; "Are we offering value to our followers with our posts?". As social media executive in Maersk declared, the company preferred to use social media as a way to connect its stakeholders by telling engaging stories and sharing useful content. However such content should not only provide pure knowledge on the company, the industry etc. but also it should sparkle dialogue and encourage getting shared. Hence it was basically highlighted that the company focused heavily on "enriching" the content of the posts in order to attract more people to be interested in their profile.

Importance of post content was also highlighted by the social media executive in Arkas and agenda, quality of content, quality of materials, visual quality, and communication tone was considered as the factors that the company paid attention while preparing their post contents. In addition, the company heavily focused on the dynamics of the events by avoiding cross-pointings as much as possible. It was basically observed that while Arkas was paying great attention to the quantifiable dimensions to be considered in content creation such as quality of materials, design etc. Maersk heavily concentrated on designing the content mostly through story-telling in order to interact with as many stakeholders as possible.

\section{Customization}

Customization is classified under two components as stakeholder customization and social media channel customization since stakeholder engagement can be successful through customized social media posts designed for both stakeholders and social media channels.

\section{Stakeholder customization}

Social media should be considered as an important interaction tool that delivers rational, functional, and reliable content, which is proper for the needs of various stakeholders. Both companies agreed that stakeholder customization is key for delivering the right message to the right audience. Since each digital media tool targets a different type of stakeholders (Kane et al. 2012, 
p.19), both of the firms differentiate their post content accordingly. Arkas implied that:

......we can apply many different methods to interact with each of our stakeholders. All of our social media tools have their own dynamics. Stakeholders, which prefer LinkedIn and Instagram, don't expect the same contents. While in LinkedIn, stakeholders can be interested in the turnover the firm has in the first quarter of the year, followers in Instagram/Facebook can be curious about new ships or new services.

Maersk declared that:

......we believe that each social media tool has the different community management capability, hence we conduct research on the ways to reach the right of the stakeholder group(s) for the specific social media tools. Maersk representative added that the social media department classified their social media channels from least to most corporate and segmented them into four sections as; fans, customers, employees, and experts. This was conducted in order to establish the right way of communication with segmented stakeholder groups.

While LinkedIn is mainly preferred for reaching young people, newly graduates, business people sharing industrial news and updates, Instagram is widely used for a wider stakeholder group including communities, customers, employees, social-interest groups. In addition, Youtube is mainly used by stakeholders (university students, graduates, business professionals, media groups) to provide the latest news regarding the company.

\section{Social Media Channel Customization}

Social media channels act as a catalyst in relationship created between firms and stakeholders. Every single social media platform has its own characteristics and it may not be appropriate to use the same content everywhere. The companies need to find the most appropriate communication methods with respect to social media based on various stakeholder groups. For instance, while more professionals in the industry mainly prefer LinkedIn and the post contents are generated based on the interests and needs of such stakeholders, Instagram may provide different posts according to its main profile. Interviews with executives and desk research showed that the companies differentiate their posts according to the type of social media tool that they are going to share the posts.

Arkas social media executive commented on the role of LinkedIn for the release of industrial news and updates about the 
company. The main target group was considered as the young people and the professionals interested in the services, investments of Arkas. In addition, increasing use of Instagram especially for visual existence was highlighted and it was dictated by Arkas executive that ".......since Arkas as a corporate organization is involved in many diversified areas such as shipping, freight forwarding, logistics, wine and olive oil production etc., we have a huge inventory of photo collection to be posted in Instagram. As the time passes, we realize that such photos from our diversified sections attract many people from all over the world."

In a case study on Maersk implied that the company employed Facebook to engage with followers in a very visual and conversational way. While Twitter is mainly preferred for news outlet, LinkedIn is considered as a more business platform to connect with their customers (Katona and Sarvary, 2014). Maersk representative added that they established The Shipping Circle LinkedIn group to include shipping experts around the world to discuss the main opportunities, problems, and challenges in the industry. Instagram was considered as a different platform where \#maersk spotting trend was launched that people from different parts of the world can take photos of Maersk ships and containers and share it on Instagram, Facebook, Twitter, etc. Maersk also used Google + Hangouts are used to establish smaller press briefings during company's new initiatives. Journalists can easily become online and conduct live videoconferences with the executives.

One of the common points indicated by both companies was about the use of Twitter in their social media communications. Arkas implied that the company does not have an official Twitter account since in case of an emergency, the company cannot receive technical support from Twitter headquarters and the company cannot take precautions regarding any comments. Maersk, on the other hand, focuses on one of the drawbacks of Twitter regarding geo-targeting. A massive drawback of Twitter is the fact that it does not allow geotargeting to certain countries or regions, requiring locally-managed Twitter accounts for local language content.

\section{Stakeholders as Operant Resources}

SDL perspective posits that companies should consider their customers, suppliers and other stakeholders as operant resources for achieving collaborative co-creation (Lusch and Vargo, 2009). Stakeholders, in general, are viewed as operant resources which are 
endogenous to both exchange and value-creation processes (Vargo and Lusch, 2006). Such value co-creation promotes mutual participation and co-operation. Since stakeholders mobilize knowledge and resources through stakeholder engagement via social media, they can be viewed as the main actors in value creation as well as co-creators and producers. In the light of this view, stakeholders are situated as the parties receiving the value propositions offered by the companies. Since stakeholders are considered as operant resources, they are accepted as the actors providing valuable feedback to the social media posts of the companies in terms of popularity, virality, and commitment. As seen in Figure 1, two-way information flow between the company (value propositions) and stakeholders is suggested to facilitate stakeholder engagement via social media. This was supported by Lusch and Webster Jr. (2011) who argued that new perspective in marketing necessitates the use of organizational connections to establish twoway information flow with all stakeholders.

When two cases are compared, stakeholder perspectives of the companies in case of social media interactions are different. Arkas concentrated heavily on customers regarding the posts including the services, investments, operations etc. since the feedback from the customers mainly shaped the way of doing business. Customers were highly mentioned by the social media executive as the main stakeholders and operant resources affecting the value propositions of the company. Another critical stakeholder group expressed by Arkas was the public and the media/press and corporate social responsibility actions, events, programmes of the company mainly targeted such stakeholder groups in order to reveal the social benefits originated by the company for the attention of a larger audience. This coincided with the argument of Roloff (2008) who classified stakeholder management types into two as organization-focused stakeholder management and issue-focused stakeholder management. While the former focuses on organization's welfare, the latter deals with the issues that affect their relationship with other societal groups and organizations. In this case, Arkas can be considered as an organization following a hybrid version of such stakeholder management strategies by ensuring that posts including both the organization-related issues and welfare and issues related to societal groups.

Maersk case showed that the company's social media strategy included as many stakeholders as possible, surely through various 
social media channels and posts. Maersk executive asserted that their main goal from the beginning of their social media journey was not to use social media for basic marketing efforts, but as a communication platform to interact closely with the customers. Maersk concentrated on encouraging the users and create content and communication rather than solely transmitting messages. On the Maersk Line social site, it was highlighted that "social media is about communication, not marketing. It is about engaging, not pushing. Social media is a mindset, a way of thinking and working together" (www.maersklinesocial.com). As an example to use stakeholders as operant resources, Maersk provided a case of employee participation via social media. In November 2012, Maersk line produced a video recording with one of its employees in order to answer a question about Hurricane Sandy that came in via Twitter. The video was published on forbes.com and broke all of the shipping company's records for most views in 24 hours. It is not only the employees and the customers that Maersk considers as operant resources in stakeholder perspective but also many other actors are also taken into account. It was highlighted in the interview that NGOs, employees, potential employees, suppliers, regulatory bodies as well as a large crowd of shipping nerds and enthusiasts were considered as relevant stakeholders to be contacted via social media. This is also supported with Roloff's (2008) categorization that Maersk as a company involved in multi-stakeholder networks pays great attention to issue-focused stakeholder management techniques. In addition, this shows that Maersk also considers non-customer stakeholders as important resources for stakeholder engagement and value co-creation. This was also highlighted by Normann and Ramirez (1993) that non-customer stakeholders are critical and they have potential to work together to co-create new forms of value.

\section{Value-in-use}

As SDL perspective identifies, companies can only provide value propositions and the value is originated during the in-use experience. As Frow and Payne (2011) pointed out, the in-use experience was not considered and studied in B2B markets. Value is not transferred from one actor to another and it is co-created in-use with the actors and value propositions provide the basis of expectations of value-in-use (Frow and Payne, 2011). As seen in Figure 1, value-in-use is established as a result of the integration between the company's value propositions and the stakeholders (as 
operant resources). Output for such value-in-use is suggested as "social media-oriented stakeholder engagement" by the authors. Desk research and interviews revealed main enablers of value-in-use as; knowledge sharing, continuous communication, and adaptation.

\section{Knowledge Sharing}

Companies should consider the co-creation of value propositions with each stakeholder market relevant to their company. This necessitates knowledge sharing, understanding stakeholder experiences and using the value propositions to achieve new knowledge and experience (Frow and Payne, 2011). From the dialogical perspective, Ballantyne and Varey (2006) argued that it included interaction and knowledge sharing between all relevant stakeholders through trust, learning, and adaptation within the marketing system. Dialogue with information sharing constitutes the basic form of knowledge in value propositions (Frow and Payne, 2011).

Lusch et al. (2006) focused on two critical competencies for enabling knowledge sharing as collaborative capability (the ability to work with other parties in an open and honest way) and absorptive capability (ability to receive new information from stakeholders and the environment). These capabilities constitute the basis of knowledge identified in value propositions. In this study, communication capability is used rather than collaborative capability since the level and intensity of communication through various social media channels determines how successful is the company with regards to delivering the messages to its stakeholders.

Interview findings of Arkas revealed that Arkas can benefit from the absorptive capability via social media. The most highlighted issue was about the innovative feedback coming from the stakeholders in both cases. For instance, following the requests of a certain number of followers regarding the launch of a new route, it is likely that a new service can be launched between certain origin and destinations. Moreover, Arkas declared that improvements in services or ideas related to new service development have great importance in their communications via social media. As Arkas executive highlighted:

Organizations may sometimes hardly notice the problematic parts of the services that they are providing. Such information exchange between the Arkas and its stakeholders reveals the things to be done, 
precautions to be taken or launching a totally new service....It is about always letting the valuable information going into the decision-making units of the organization."

A similar approach was also considered in Maersk case that they Maersk has become open to all discussions and exchange of ideas with their stakeholders through social media channels and this mainly results in the co-creation of their novel services. Social media executive also highlighted that they tried their best to be transparent and proactive in their social media communications. They did not only concentrate on the bright side of the business by sharing the good news regarding the company but also bad news as well. For instance, a post about a whale that was scooped up by a Maersk ship on the way to the port of Rotterdam was shared on Facebook.

\section{Continuous Communication}

The continuity of communication between the firm and the stakeholder is crucial to keeping relationships alive (Duncan and Moriarty, 1998; Grönross, 2004). Communication process supported by dialogue, asking and answering questions is considered as a key for interacting with customers (Vargo and Lusch, 2004). Considering literature, case study results showed a similar pattern. About this subject, Maersk declared that:

We are responding to comments and inquiries through both direct messages and comments to our posts in almost real time, always verifying the facts with internal stakeholders. We are following a simple "trylisten-learn-redo-fun-lean" perspective in order to explore the attitudes of our stakeholders and to try different social media channels to reach them.

Similarly, Arkas pointed out that:

We are in constant contact with all of our stakeholders. We create solutions for users who transmit their requests through our website or through our social media channels.

Although customers are considered as the most critical stakeholder for both companies, the executives provided examples of interactions with another stakeholder as well. This was also supported by Vargo and Lusch (2009) that not only customers but also employees and other relevant stakeholders should be included in the communication processes. Storytelling was considered as the 
keyword to make a connection with a larger audience via social media. In its social media journey, Maerks started posting "boring photos" at the initial stage but then it was discovered that Maersk had a digital archive with 14.000 photos of ships, seascapes, and ports. This was considered as a valuable way of making connections with stakeholders since such photos enriched with related stories were unique to Maersk (Katona and Sarvary, 2014).

\section{Sensing and Adaptation}

Ballantyne and Varey (2006) pointed out that companies can understand their mutually shared benefits through sensing and learning. This brings out the capability of adaptation not only with the content of the posts but also with the way that the companies engage with their stakeholders. According to the findings of the interviews, such sensing and learning practices were experienced through the use of various techniques. As Arkas executive argued:

We heavily rely on sincere and honest communication with our stakeholders and empathy is actually the keyword to adapt ourselves to the changing needs and views of various stakeholders. Transparency is also critical.... When we send a post with full transparency, stakeholders understand its value and develop attitudes accordingly. We just focus on transmitting the message and the rest is totally about how the stakeholders perceive it.

Arkas executive also declared that listening to what the stakeholders say in their messages was basically the company's priority in achieving value co-creation. This was also about understanding what the feedback actually says to the company. Especially Arkas's posts regarding its activities about art (exhibitions, sponsorships etc.) and sports were considered critical by the company and posts regarding such areas were continuously revised and updated based on stakeholders' feedback. Demographic data played a very important role for such revisions and updates. An interesting finding regarding Arkas was that the humoristic and touching language they used in their messages with stakeholders contributed enormously to their value co-creation efforts in terms of stakeholder engagement (especially on special occasions). The company realized that such change in language use had a very positive impact on the engagement levels as well. 
Maersk case is quite similar to Arkas in many ways. However, the examples extracted both from the transcripts and findings of Katona and Sarvary's (2014) study revealed that Maersk concentrated on the use of specific moves to become more adaptive and sensitive to the stakeholders' feedback. For instance, Maersk paid attention to the public and users interested in taking photos from different parts of the world. Maersk posted photos of Maersk ships from various parts of the world along with the commentaries by saying "A Maersk ship passing under the Golden Gate Bridge. Thank you to.... who was so kind to e-mail the photo to us."

According to the findings of the interviews and the desk research, it was seen that the two companies had different perspectives on the adaptation component of value-in-use. While Arkas heavily focuses on "listening" to the stakeholders, analyzing their feedback accordingly and configuring the next social media posts, Maersk focuses more on "involving" the stakeholders to the value co-creation process through adapting itself. Maersk also concentrated on analyzing the feedback, however, the company managed to listen and adapt its messages through the building of a unique language with the stakeholders.

\section{Conclusions and Implications}

This study attempted to contribute to the emerging B2B social media marketing literature by providing an overview of stakeholder engagement through social media interactions of two selected cases. Proposed theoretical themes as shown in Figure 1 were discussed in accordance with the findings of the cases. Value propositions were discussed under two main components as customization (stakeholder and social media channel) and post content creation. Building upon Frow and Payne's argument on stakeholders as to be viewed as resources, this study suggested that the stakeholders should be considered as operant resources, which facilitate the interaction via social media and provide valuable feedback to the companies in terms of virality, popularity, and commitment. Moreover ideas regarding innovation, service development, service failures etc. were considered critical for the companies to evaluate the feedback and respond to it. Presenting the stakeholders as operant resources revealed the stakeholders' contribution to the value co-creation process. Since company's value propositions should consider all stakeholders who must see the potential value in the value propositions (Frow and Payne, 2011), a 
special attention should be given to the customization in stakeholders and social media channels. Value propositions enriched by stakeholder customization and social media channel customization should be communicated to the whole resourceproviding stakeholders in the social media value-creation network of the company. The value proposition is the way that the company proposes to affect the resource-providing stakeholders by defining the main outcome. Such outcome is defined with regards to the value-in-use concept in the study. As main enablers of value-in-use, knowledge sharing, continuous communication and sensing and adaptation were revealed. Haeckel (1999) suggested "sense-andrespond" concept in building close relationships with stakeholders and social media was considered as supporting tool for enriching the flow of knowledge, experience, and expertise between the company and its stakeholders. This was supported by Ballantyne and Varey (2006) that knowledge sharing and dialogue were critical components in value creation. In addition, Frow and Payne (2011) suggested that facilitating dialogue and knowledge sharing as one of the steps for value co-creation in stakeholder concept.

To be truly stakeholder-centric, companies should consider not only optimizing the company and its both operand and operant resources but also should look for ways to support stakeholders in their resource integration and value co-creation processes. Container shipping is an industry where many actors are involved in the service exchanges. In such network world, many stakeholders are active in sharing various feedback with the companies and namely co-creating value. It is the companies' responsibility to combine their own value propositions with the feedback originating from stakeholders as operant resources and establish value-in-use enriched with the characteristics of industry dynamics.

As for theoretical implications, stakeholder engagement from SDL lens was considered and the role of social media from such perspective was firstly investigated with emergent framework specifically for the shipping industry. Although there has been considerable research in stakeholder management field (Scherer and Patzer (2011), an aspect of value creation is relatively limited (Garriga, 2014). Ballantyne and Varey (2005) concentrated on the dialogical perspective involving communication and knowledge sharing among all stakeholders. This was supposed to be conducted through trust, learning, and adaptation and it was supported by the findings of the study as well. One of the enablers of value-in-use was 
suggested as sensing and adaptation since understanding what the stakeholders actually presented as a result of interaction constituted the basis of value co-creation. This study provides support to the commentators who have suggested that stakeholders can be considered as groups to be recognized in building relationships (Gumesson, 2002; Frow and Payne, 2011) and who argued that social media can be an effective tool for stakeholder engagement and value co-creation (Morsing et al. 2006; Lovejoy et al. 2012; Bonsón and Ratkai, 2013).

Container shipping companies need to understand the main challenges and opportunities introduced by social media. Any drawback to the constitution of value-in-use with regards to limited knowledge sharing, continuous communication or sensing and adaptation may negatively affect the interactions with their stakeholders. Hence shipping companies need to identify and then listen to their resource-providing stakeholders via social media. Stakeholder engagement may help the companies to consider the opportunities offered by social media use and value propositions offered may be updated or restructured depending on the dynamics of the container shipping industry. It was observed that shipping industry is in its infancy regarding the social media use compared to the logistics service providers and stakeholder engagement via social media has not been actively recognized. Companies should also monitor the feedback originating from their various stakeholders (not only from customers) and align their marketing strategies with their stakeholder relationship strategies as well as social media strategies.

\section{Limitations and Further Research}

The findings of the present article address the call for more focus on stakeholders in value co-creation through social media interactions. The study has been conducted in a specific sector and at a specific point in time. Since one of the social media executives was in Denmark (a company headquartered in Denmark), e-mail interviews were conducted rather than face-to-face interviews. Since the literature regarding both stakeholder engagement via social media and its reflections on shipping industry is limited, no previous research in case of shipping was observed. In addition, stakeholder engagement via any specific social media tool (e.g. Facebook, Twitter) was not considered and investigated in detail. Since stakeholder engagement via social media is in its infancy in the 
shipping industry, an understanding regarding the overall value cocreation concept via stakeholder engagement and social media was studied. These were considered the main limitations.

There is substantial room for further research. First, it would be convenient to understand whether the findings generated in this study are relevant to other industries. Second, the evaluation of social media usage is a relatively new concept for the literature. Thus, a similar study can be repeated in the future as a longitudinal study. Thirdly, since know-how related to social media is limited, the interviews were conducted with only one expert, namely the social media manager. So, as a future research idea considering the holistic approach, the study can be repeated with the interviews and the contributions of the operation and/or marketing managers. Same research framework can be applied to one group of stakeholder instead of whole stakeholder groups. An in-depth investigation through focus groups with representatives from both social media companies and shipping industry can also be conducted in order to elaborate the main missing points and opportunities.

\section{References}

ABELA, Andrew and Patrick MURPHY (2008), "Marketing with Integrity: Ethics and The Service-Dominant Logic for Marketing", Journal of the Academy of Marketing Science, Vol.36 No:1, pp.39-53.

ADAMS, Gerald and Jay SCHVANEVELDT (1985), Understanding Research Methods. $2^{\text {nd }}$ Edition, Longman Inc., New York.

AGERDAL-HJERMIND, Annette. (2014). "The Enterprise Social Media Relations Strategy: The Case of Maersk Line", Communication \& Language at Work, Vol.3, No:3.

AGNIHOTRI, Raj, DINGUS, Rebecca, HU, Michael, and Michael KRUSH (2016), "Social Media: Influencing Customer Satisfaction In B2B Sales", Industrial Marketing Management, Vol:53, pp. 172-180.

ANDRIOF, Jörg and Sandra WADDOCK (2002), "Unfolding stakeholder engagement", (eds) J. Andriof, Jörg and Waddock, Sandra, Husted, Bryan and Sandra Sutherland, Unfolding Stakeholder Thinking: Theory, Responsibility and Engagement, Greenleaf Publishing Limited, Sheffield.

BADEN, Denise (2010), "CSR: An Opportunity for SMEs", (eds) Louche, Celine, Idowu, Samuel and Walter Filho, Innovative CSR: From 
Risk Management to Value Creation, Greenleaf Publishing Limited, Sheffield.

BALLANTYNE, David and Richard VAREY (2006), "Introducing A Dialogical Orientation to The Service-Dominant Logic of Marketing", (eds) Robert L. Lusch, and Stephen L. Vargo, The Service-Dominant Logic of Marketing: Dialog, Debate and Directions, M.E. Shape, Armonk, NY.

BLANEY, Bill (2013). B2B A to Z: Marketing Tools and Strategies That Generate Sales Leads for Your Business-to-Business Company, Denham Publishing, USA.

BONSON, Enrique and Melinda RAKAI (2013), "A Set of Metric to Assess Stakeholder Engagement and Social Legitimacy on a Corporate Facebook Page", Online Information Review, Vol.37, No: 5, pp.787-803,

BRYMAN, Alan and Emma BELL (2011), Business Research Methods. 3rd Edition, Oxford University Press. Oxford.

CASSELL, Cathy and Gillian SYMON (1994), "Qualitative Research in Work Context", (eds) Catherine Cassell and Gillian Symon, Qualitative Methods in Organizational Research a Practical Guide, Sage, London.

CLARKSON, Max (1995), "A Stakeholder Framework for Analyzing And Evaluating Corporate Social Performance", Academy of Management Review, Vol.20, pp. 92-117.

CLULOW, Val (2005), "Futures Dilemmas for Marketers: Can Stakeholder Analysis Add Value?" European Journal of Marketing. Vol.39, No: 9/10, pp.978-997.

CONSTANTIN, James and LUSCH, Robert (1994). Understanding Resource Management, The Planning Forum, Oxford.

CORDING, Margaret, HARRISON, Jeffrey, HOSKISSON, Robert and Karsten JONSEN (2014), "Walking the Talk: A Multi-Stakeholder Exploration of Organizational Authenticity, Employee Productivity and Post- Merger Performance", Academy of Management Perspectives, Vol.28, No: 1, pp.38-56.

CRESWELL, John and Dana MILLER (2000). "Determining Validity in Qualitative Inquiry", Theory into Practice, Vol.39, No: 3, pp. 124-130.

CRESWELL, John (2007), Qualitative Inquiry and Research Design: Choosing Among Five Approaches, 2 ${ }^{\text {nd }}$ edition, CA:Sage, Thousand Oaks.

DUNCAN, Tom and Sandra MORIARTY (1998), "A Communication-Based Marketing Model for Managing 
Relationships", Journal of Marketing, Vol.62, No: 2, pp.1-13.

EISENHARDT, Kathleen (1989), "Building Theories from Case Study Research", Academy of Management Review, Vol: 14 No: 4, pp.532-550,

FREEMAN, Edward (1984), Strategic Management: A Stakeholder Approach, Pitman Boston.

FREEMAN, Edward, HARRISON, Jeffrey and Andrew WICKS (2007), Managing For Stakeholders: Survival, Reputation, and Success. Yale University Press, New Haven.

FROW, Pennie and Adrian PAYNE (2011), "A Stakeholder Perspective of the Value Proposition Concept", European Journal of Marketing, Vol.45, pp.223-240.

GARRIAGA, Elisabet (2014), "Beyond Stakeholder Utility Function: Stakeholder Capability in the Value Creation Process", Journal of Business Ethics, Vol.120, pp. 489-507.

GILLIN, Paul and Eric SCHWARTZMAN (2011), Social Marketing to the Business Customer: Listen to Your B2B Market, Generate Major Account Leads, and Build Client Relationships. John Wiley \& Sons, New Jersey.

GOULD, Robert (2012), "Open Innovation and Stakeholder Engagement", Journal of Technology Management and Innovation, Vol.7 No: 3, pp.1-11.

GRÖNROOS, Christian. (2008), "Service Logic Revisited: Who Creates Value? And Who Co-creates?" European Business Review, Vol: 20 No: 4 pp.298-314.

GRÖNROOS, Christian and Annika RAVALD (2011), "Service as Business Logic: Implications for Value Creation and Marketing", Journal of Service Management, Vol. 22 No. 1, pp. 5-22.

GRÖNROSS, Christian (2004), "The Relationship Marketing Process: Communication, Interaction, Dialogue, Value" Journal of Business \& Industrial Marketing, Vol: 19 No: 2, pp. 99-113.

GRÖNROSS, Christian (2011), "Value Co-Creation in Service Logic: A Critical Analysis", Marketing Theory, Vol: 11 No: 3, pp.279$\underline{301 .}$

GUMMESSON, Evert (2002), "Internal MARKETING IN THE LIGHT OF RELATIONSHIP MARKETING AND NETWORK ORGANIZATIONS", (ed) Barbara Lewis and Richard Varey, Internal Marketing: Directions for Management, Routledge: London.

GUMMESSON, Evert (2008), "Extending the Service-Dominant Logic: From Customer Centricity to Balanced Centricity", Journal of the Academy of Marketing Science, Vol: 36, pp. 15-17. 
HAECKEL, Stephan (1999), Adaptive Enterprise: Creating and Leading Sense-and-Respond Organizations, Harvard Business Press.

HILLEBRAND, Bas, DRIESSEN, Paul and Oliver KOLL (2015), "Stakeholder Marketing: Theoretical Foundations and Required Capabilities", Journal of the Academy of Marketing Science, Vol: 43 No: 4, pp.411-428.

HOFFMANN, Christian and Christoph LUTZ (2014), "The Impact of Online Media on Stakeholder Engagement and The Governance Of Corporations", Journal of Public Affairs, Vol:15 No:2

HUOTARI, Lauri, ULKUNIEMI, Pauliina, SARANIEMI, Saila and Minna MALASKA (2014), "Analysis of Content Creating In Social Media By Companies", Journal of Business \& Industrial Marketing, Vol: 30 No: 6, pp. 761-770.

JÄRVINEN, Joel, TOLLINEN, Aarne, KARJALUOTO, Heikki and Chanaka JATAWARDHENA, (2012), "Digital And Social Media Marketing Usage In B2b Industrial Section", The Marketing Management Journal, Vol: 22 No:2, pp. 102-117.

JAWAHAR, I.M. and Gary MCLAUGHLIN (2001), "Toward a Descriptive Stakeholder Theory: An Organizational Life Cycle Approach", Academy of Management, Vol.:26 No: 3, pp.397-414.

JURGENS, Michele, BERTHON, Pierre, PAPANIA, Lisa and Haseeb SHABBIR (2010), "Stakeholder Theory and Practice in Europe And North America: The Key To Success Lies in a Marketing Approach" Industrial Marketing Management, Vol: 39, pp. 769-775.

JUSSILA, Jari, KARKKAINEN, Hannu and Maija LEINO (2012), "Social Media's Opportunities in Business-to-business Customer Interaction in Innovation Process", International Journal of Technology Marketing, Vol: 7 No: 2, pp.191-208.

KANE, Gerald, ALAVI, Maryam, LABIANCA, Giuseppe and Stephen BORGATTI (2012), "What's Different about Social Media Networks? A Framework and Research Agenda", MIS Quarterly Forthcoming, No: 1, pp. 1-38.

KATONA, Zsolt and Miklos SARVARY (2014), "Maersk Line: B2B Social Media - "It's Communication, Not Marketing", BerkeleyHaas Case Series. Vol: 56 No: 3, pp.142- 156.

KEINÄNEN, Hanna, and Olli KUIVALAINEN (2015), "Antecedents of social media B2B use in industrial marketing context: Customers' view", Journal of Business \& Industrial Marketing, Vol: 30 No: 6, pp. 711-722.

KRICK, Thomas, FORSTATER, Maya, MONAGHAN, Philip and Maria SILANNPÄÄ (2005), From Words to Action. The Stakeholder 
Engagement Manuel. Volume 2: The Practitioner's Handbook on Stakeholder Engagement.

KRUMAY, B. \& GEYER, S., (2016). The Role of Social Media for Stakeholder Involvement: A Literature Review. BLED Proceedings eConference.

LACZNIAK, Gene (2006), "Some Societal and Ethical Dimensions of The Service-Dominant Logic Perspective of Marketing", (ed) Robert Lusch and Stephan Vargo, The Service Dominant Logic of Marketing: Dialog, Debate and Directions, Sharpe, Armonk, New York: M.E.

LINCOLN, Yvonna and Egon GUBA (1985), Naturalistic inquiry. Newbury Park, CA: Sage.

LOVEJOY, Kristen and Gregory SAXTON (2012), "Information, Community, and Action: How Nonprofit Organizations Use Social Media", Journal of Computer-Mediated Communication, Vol: 17, pp. 337-353.

LUSCH Robert and Frederick WEBSTER (2011), "A Stakeholder-unifying, cocreation Philosophy for Marketing", Journal of Macromarketing, Vol: 31 No: 2, pp.129-134.

LUSCH, Robert, VARGO, Stephen and Alan MALTER (2006), "Marketing as Service-Exchange: Taking a Leadership Role in Global Marketing Management", Organizational Dynamics, Vol: 35 No: 3, pp.264-278.

LUTZ, Christoph and Christian HOFFMANN (2013), "The Impact of Social Media on Stakeholder Engagement", Conference ICA Preconference "Governance through communication: stakeholder engagement, dialogue, and corporate social responsibility" Edinburgh

MC CARTHY, Jeff, ROWLEY, Jennifer, ASHWORTH, Catherine, and Elke PIOCH (2014), "Managing Brand Presence through Social Media: The Case of UK Football Clubs", Internet Research, Vol: 24 No: 2, pp. 181-204,

MICHAELIDOU, Nina, SIAMAGKA, Nikoletta and George CHRISTODOULIDES (2011), "Usage, Barriers and Measurement of Social Media Marketing: An Exploratory Investigation of Small and Medium B2B Brands", Industrial Marketing Management, Vol. 40, pp. 1153-1159.

MILLER, Lee and William LEWIS (1991), "A Stakeholder Approach to Marketing Management Using the Value Exchange Models", European Journal of Marketing, Vol: 25 No: 8, pp.55-68.

MORSING, Mette and Majken SCHULTZ (2006), "Corporate Social Responsibility Communication: Stakeholder Information, 
Response and Involvement Strategies", Business Ethics: A European Review, Vol: 15 No: 4, pp.323-338.

NELSON, Jane and ZADEK (2000), Partnership Alchemy: New Social Partnerships in Europe. Copenhagen: Copenhagen Centre.

NORMANN, Richard, and Rafael RAMIREZ (1993), "From Value Chain to Value Constellation: Designing Interactive Strategy", Harvard Business Review, Vol.71, pp. 65-77.

PARMAR, Bobby, FREEMAN, Edward, HARRISON, Jeffrey, WICKS, Andrew, DE COLLE, Simone and Lauren PURNELL (2010), "Stakeholder Theory: The State of The Art", The Academy of Management Annals, Vol: 3 No: 1, pp. 403-445,

PAYNE, Adrian, STORBACKA, Kaj and Pennie FROW (2008), "Managing The Co-Creation of Value", Journal of the Academy of Marketing Science, Vol: 36 No: 1, pp.83-96

PAYNE, Adrian, and Pennie FROW (2005), "A Strategic Framework for Customer Relationship Management, Journal of Marketing, Vol: 69, pp.167-176.

PAYNE, Adrian, BALLANTYNE, David, and Martin CHRISTOPHER, (2005), "A Stakeholder Approach to Relationship Marketing Strategy: The Development and Use of the Six Markets Model", European Journal of Marketing, Vol: 39 No:7/8, pp.855871.

PEDERSEN Esben (2006), "Making Corporate Social Responsibility (CSR) Operable: How Companies Translate Stakeholder Dialogue into Practice", Business and Society Review, Vol: 111 No: 2, pp. 137-163.

RAPP, Adam, BEITELSPACHER, Lauren, GREWAL, Dhruv, and Douglas HUGHES (2013), "Understanding Social Media Effects Across Seller, Retailer, and Consumer Interactions", Journal of the Academy of Marketing Science Vol: 41 No:5, pp. 547-566.

ROLOFF, Julia (2008), "Learning from Multi-Stakeholder Networks: Issue-Focused Stakeholder Management", Journal of Business Ethics, Vol. 82 No. 1, pp. 233-250.

SCHERER, Andreas and Moritz PATZER (2011), "Where Is the Theory in Stakeholder Theory? A Meta-Analysis of the Pluralism in Stakeholder Theory". In R. A. Philips (Ed.), Stakeholder Theory: Impact and Prospects, Cheltenham: Edward Elgar.

SEN, Sankar, BHATTACHARYA, C. B., and Daniel KORSCHUN (2006). "The Role of Corporate Social Responsibility in Strengthening Multiple Stake- Holder Relationships: A Field Experiment”, Journal of the Academy of Marketing Science, Vol: 34 No: 2, pp. 158-166. 
SIAMAGKA, Nikoletta, CHRISTODOULIDES, George, MICHAELIDOU, Nina and Aikaterini VALVI (2015), "Determinants of Social Media Adoption by B2B Organizations", Industrial Marketing Management, Vol. 51, pp. 89-99

SMITH, Craig, ANSETT, Sean and Lior EREZ (2011), "How Gap Inc. Engaged with Its Stakeholders", MIT Sloan Management Review, Vol: 52 No: 4, pp.69-76.

STAKE, Robert (2005), "Qualitative Case Studies". (eds) Norman K. Denzin and Yvonna S. Lincoln, SAGE Handbook of Qualitative Research, SAGE, Thousand Oaks.

TRAINOR, Kevin (2012), "Relating Social Media Technologies to Performance: A Capabilities-Based Perspective", Journal of Personal Selling \& Management, Vol: 32 No: 3, pp. 317-331.

UNERMAN, Jeffrey (2007), "Stakeholder Engagement and Dialogue", (eds) Jeffery UNERMAN, Jan BEBBINGTON and Brendan O'DWYER, Sustainability Accounting and Accountability, Routledge.

VARGO, Stephen and Robert LUSCH (2009), A ServiceDominant Logic for Marketing, (eds) Stephen VARGO and Robert LUSCH,SAGE Handbook of Marketing Theory. SAGE Publications Inc.

VARGO, Stephen (2009), "Toward a Transcending Conceptualization of Relationship: A Service-Dominant Logic Perspective", Journal of Business and Industrial Marketing, Vol: 24 No: 5/6, pp.373-379.

VARGO, Stephen and Robert LUSCH, (2004), "Evolving a New Dominant Logic for Marketing", Journal of Marketing, Vol: 68 No: 1 , pp. 1-17.

VARGO, Stephen and Robert LUSCH (2006), "Service Dominant Logic: What it is, What it is not, what it might be", (eds) Stephen VARGO and Robert LUSCH, Service-Dominant Logic of Marketing: Dialog, Debate and Directions, Armonk: M.E. Sharpe.

VARGO, Stephen and Robert LUSCH (2008), "Why "service"?, Journal of the Academy of Marketing Science, Vol: 36, pp. 25-38.

VARGO, Stephen, LUSCH Robert and Fred MORGAN (2006), “ Historical Perspectives On Service-Dominant Logic". ”, (eds) Stephen VARGO and Robert LUSCH, Service-Dominant Logic of Marketing: Dialog, Debate and Directions, Armonk: M.E. Sharpe.

VELDMAN, Celine, VAN PRAET, Ellen, and Peter MECHANT (2015), "Social Media Adoption in Business-To-Business; IT And Industrial Companies Compared", International Journal of Business Communication, Vol. 1 No. 23, pp. 1-23. 
VERNUCCIO, Maria. (2014), "Communicating Corporate Brands through Social Media an Exploratory Study", International Journal of Business Communication, Vol: 51 No: 3, pp.211- 233.

WADDOCK, Sandra (2005), Leading Corporate Citizens: Vision, Values and Value Added. New York: McGraw-Hill.

WICHMANN, Jonathan (2013), The Next Step: How to Unlock the Full Potential of Social Media. Maersk Line: Copenhagen.

YIN, Robert (2003), Case Study Research, Design and Methods. Thousand Oaks: Sage.

\section{Web References}

Arkas. (2017). Arkas Holding. http://www.arkas.com.tr/en/arkas holding.html (Accessed to: 27/07/2017)

CABIE, S. (2012, 13 July). Maersk Line sets B2B Social Media Example, https://simply-communicate.com/maersk-line-sets-b2bsocial-media-example/ (Accessed to: 07/07/2017). 
324 | Manisa Celal Bayar Üniversitesi Sosyal Bilimler Dergisi - Cilt: 17, Sayı: 2, Haziran 2019 